\title{
Service Life of Railway Wood Sleepers in Indonesia
}

\author{
Djarwanto, Sihati Suprapti, and Sri Rulliaty
}

\begin{abstract}
Wood offers natural advantages tremendously such as their elasticity, flexibility and resistance against compression as well as force impact. Therefore, wood material is astonishingly better material than concrete for railway sleepers. In spite of wood material's advantages, the material is susceptible to attack by organisms. This paper observes the service life of wood sleepers in Java, Indonesia. Wood sleepers were observed visually from the ground railway system, Banten Province includes wood species identification macroscopically and organism's attack. Results reveal that natural wood resistance of the sleepers are relatively high, then sleepers were predicted to be last long. Sleepers wood species are teak (Tectona grandis), balau (Hopea sp.), merbau (Intsia bijuga), and ulin (Eusideroxylon zwageri). Sleepers were also found deteriorated by fungus during five months instalment. Decaying fungi observed are Dacryopinax sp., D. spathularia, Lentinus sp., Panus sp., Pycnoporus sp., P. sanguineus, Polyporus spp., Schizophyllum commune, and Trametes sp.
\end{abstract}

Keywords: service life, wood sleeper, wood-degrading organisms, fungi.

\section{Introduction}

Conventionally, wood material is used for railway sleepers, as it offers remarkably natural advantages such as flexibility, resilience, elasticity and its resistance against compression as well as impact, which are better than those of the concrete counterparts. The preference of using wood material for sleepers is due to their ability to absorb a sudden shock, low conductivity of heat as well as electric, and convenience for train to pass by. In addition, wood for railway sleepers are easily prepared and shaped in accordance with the desired necessities, e.g. sizes, dimensions, patterns, etc (FORPRIDECOM 1971). As of this occasion there are still no artificial material with their capability able to compete with the versatility of natural properties of woods for railway sleepers. Moreover, being renewable, woods for such use can ensure more environmentally friendly situation than non-renewable material (e.g. concrete). Wood species with high class durability is recommended for railway sleepers, however durable wood is hardly found in the forest. Then, concrete and steel are used for sleepers due to the lack of high durability wood supply (Djarwanto et al. 2007). For use as railway sleepers, wood should comply with the desired quality requirements and other related aspects, such as strength properties, spike-holding power, durability, expended costs, and continual availability (FORPRIDECOM 1974).

Djarwanto et al. (2007) asserted that in the last decades, wood sleepers have been used only as temporary replacement for concrete sleepers or during the maintenance of rails, particularly on the connection between concrete sleepers, at sharp turns, and on bridges. Besides, very seldom are the wood sleepers used for the permanent construction of new railways. Despite the limited use of wood sleepers for such (e.g. just replacement, maintenance, and connection), the wood consumption for railways in fact is quite enormous. Most of that wood consumption so far is still unable to be realized in accordance with the real demand, due to difficulty in procuring wood stuffs in adequate quantity.

Further, other aspects that deserve serious and thorough attention with regard to the use of wood for railway sleepers are that particularly wood stuffs could sooner or later sustain their damages and deterioration. The wood destruction and deterioration, as alleged by Martawijaya (1961), could be brought about by several factors such as physics (e.g. temperature, humidity, and sunlight), mechanical wear (friction and impacts), and biology (i.e. wood-destroying organisms). FORPRIDECOM (1971) indicated that main causes of wood failure as railway sleepers are wood decay, followed in lesser intensity by consecutively wood splitting (due to mainly humidity changes and withstanding heavy burden of metal rails and moving-trains above), deterioration or corrosion of rail-metal fastener, rail cutting or breaking, and spike rotting. All of these factors can affect the service life of wood sleepers for railways. In relevant, in order to get preliminary illustration regarding the service life and replacement of railway wood sleepers, research has been conducted on the installed wood sleepers with the aims to asses and scrutinize their resistance against wood-destroying organisms

\section{Materials and Methods}

\section{Resistance and Damages of Wood Sleepers}

Research regarding to the resistance of wood sleepers for railways was carried out at Rangkasbitung, Banten Province. The specimens of wood sleepers in dimension of $200 \mathrm{~cm}$ by $13 \mathrm{~cm}$ by $22 \mathrm{~cm}$, which were already installed by the State-Owned Railway Enterprise at the tenth railways (rail-10). Those $10^{\text {th }}$ railways served as one of the parking sites for trains at night, and also as the sites for them to pass regularly from morning to afternoon. 
Observation and in-depth scrutiny on wood species already installed as railway sleepers were conducted in 2002, and such undertaking covered as many of 240 wood sleepers which were installed as in May 2002. Identification on the wood species at the installed railway sleepers was performed on sites through macroscopic observation, and comparing as well as matching them with the available wood collection set owned by the 1915's Xylarium Bogoriense, under the Forest Products Research and Development Center, Bogor. Meanwhile, observation on the damages of the railway wood sleepers was conducted in stages that lasted for 3 years, which comprised consecutively 1 st, $2^{\text {nd }}$ and $3^{\text {rd }}$ stages that each occurred in the same month (May). After the $3^{\text {rd }}$ stage, the observation for such was terminated as those of $10^{\text {th }}$ railways were no longer used as the parking site for trains.

\section{Service Life of Wood Sleepers}

Observation on the service life of railway wood sleepers was carried out in West Java and its vicinities (i.e. Jakarta, Rangkasbitung, Bogor, Purwakarta, Sukabumi, Bandung, Cirebon, Yogyakarta and Surakarta). The observations were conducted by purposive sampling method by observing as well as identifying wood species for railways and wood-destroying organisms at the passable, achievable, and accessible locations. Study sites were randomly selected, and the wood sleepers were examined and comprised with those of ordinary railway sleepers (for regular uses); and the sleepers at consecutive connection between concrete sleepers $(200 \mathrm{~cm}$ by $13 \mathrm{~cm}$ by $22 \mathrm{~cm}$ size), at the sharp turns as well as at the crossings (300 400 $\mathrm{cm}$ by $13 \mathrm{~cm}$ by $22 \mathrm{~cm})$, and at the bridges (200 $\mathrm{cm}$ by $22 \mathrm{~cm}$ by $18 \mathrm{~cm}$ ).

Sleeper's damages were examined visually using modified grade system in accordance with that of Suprapti and Djarwanto (2001) and that of Amemiya and Matsuoka (1979) as follows:

$0=$ sound (intact, no damages at all)

$1=$ partially slight damages (slight cracks)

2 = moderate damages (small cracks few; large cracks numerous)

$3=$ partially severe damages (large cracks moderate, end cracks)

$4=$ wholly severe damages (large cracks numerous, split)

$5=$ destroyed completely (damaged to pieces)

Table 1. Classification of wood resistance based on their service life

\begin{tabular}{clc}
\hline Class & \multicolumn{1}{c}{ Resistance } & Service live (years) \\
\hline I & Very resistant & $\geq 8$ \\
\hline II & Resistant & $6 \sim 7$ \\
\hline III & Moderately resistant & $4 \sim 5$ \\
\hline IV & Non-resistant & $2 \sim 3$ \\
\hline V & Perishable & $<2$ \\
\hline Source: & ev $(1990)$ &
\end{tabular}

Source: Oey (1990)
Wood durability was categorized into five classes with regard to service life of railway wood sleepers, as presented in Table 1.

\section{Results and Discussion}

Based on the data from the State-Owned Railway Enterprise, the wood species as used for installment of wood sleepers on the tenth railways (rail-10) in Rangkasbitung Station was balangeran wood (Shorea balangeran Korth.). However, results of identification disclosed that those wood sleepers were prepared and shaped from consecutively 7 different species that comprised balangeran (Shorea balangeran Korth.) as many 134 sleepers, bintangur (Calophyllum sp.) 62 sleepers, kempas (Koompassia malaccensis Maing.) 30 sleepers, merbau (Intsia bijuga O.K.) 7 sleepers, rasamala (Altingia excelsa Noronha) 3 sleepers, balau (Hopea sp.) 2 sleepers, and pasang wood (Querqus sp.) 3 sleepers, as presented in Table 2. Those woods were regarded as inferior qualities, as they were originated from small-diameter logs which still contain high portion of juvenile wood, whereby the sapwood was clearly visible on the edge part of the sleepers. According to the State-Owned Railway Enterprise (Peraturan Dinas No. 10 Perusahaan Jawatan Kereta Api, 1986), the requirements of wood for railway sleepers were among others being intact, solid, without knots, and, no biological defects (e.g. no borer holes and no decay).

As presented in Table 2, the degree of wood damages at the railway sleepers one year after being installed was relatively slight damage. However, at the third year after installment, their degree of damages became rather severe, and consequently those wood sleepers at the tenth railways were no longer used as the parking sites for trains. The reason was that the speed of the train traffic was rather slow, train mobility low, and the frequency of train traffic there not so busy and so often. Therefore, most of the wood sleepers with light or slight damaged were moved to other railway locations where the train traffic was more active or frequent. The wood stuffs for the railway sleepers belonged to class III, according to Oey (1990), and it is estimated that their service life could last for 4-5 years. Consequently, in order to that service life could last longer, the wood stuffs should be preserved before installment. Based on Indonesia National Standard No. 0197:2013 (BSN 2013), the wood material for railway sleepers should belong to class II, or should be previously preserved or treated. Djuber (1977) asserted that several wood species must be preserved prior to service were among others Shorea balangeran, Calophyllum sp., and Koompassia malaccensis.

Djarwanto and Abdurrohim (2000) alleged that wood species that belonged to class III-IV, when used for construction purposes (including railway sleepers), should be initially treated with CCB or CCF by employing the socalled vacuum-pressure or double-diffusion process. Therefore, those seven wood species, as already used by 
the State-Owned Railway Enterprise for railway sleepers, urgently necessitated the preservation process, before their installment at the railways. Djarwanto and Suprapti (2008a) reported that Altingia excelsa which was already preserved with CCB using double-diffusion process and then installed as the railway sleepers were still in good condition after 6 years service. Martawijaya (1961) asserted that the service life of untreated bintangur wood (Callophyllum sp.) used for railway sleepers could last for 3 years. However, when those sleepers were treated with copper-naphthenate, resex and boliden bis salt separately, their life service could be improved by 9 years and 8 years, respectively.

According to the State-Owned Railway Enterprise (Peraturan Dinas No. 10 Perusahaan Jawatan Kereta Api, 1986), wood preservation is the most problem in wood sleepers. Meanwhile, based on the data, railway wood sleepers which were not treated exhibited their service life for just 3-5 years. Consequently 3-4 years after their installment, the tenth railways were no longer used for the train parking. Conversely, the enterprise asserted that the wood sleepers which were treated could afford their life service longer than 18 years. The FAO (1957) recommended that in order to increase the service life of wood sleepers, they should be treated with oil-soluble preservatives using the so-called vacuum-pressure method. Amemiya and Matsuoka (1979) asserted that balau (Shorea $\mathrm{sp.)}$, bangkirai (Shorea sp.), and borneo oak (Quercus sp.) woods belonged to class I, thereby enabling their service life to last for 9 years. Meanwhile, kapur wood (Dryobalanops $\mathrm{sp}$.) belonged to class II, which was afforded their service life for 7 years.

Table 2. Species of wood as installed on the $10^{\text {th }}$ railways in Rangkasbitung

\begin{tabular}{|c|c|c|c|c|c|c|c|}
\hline \multirow[t]{2}{*}{ No. } & \multirow[t]{2}{*}{ Wood species } & \multirow{2}{*}{$\begin{array}{l}\text { Number of } \\
\text { specimens }\end{array}$} & \multicolumn{3}{|c|}{ Degree of damages on year } & \multirow{2}{*}{$\begin{array}{l}\text { Durability } \\
\text { class }^{*}\end{array}$} & \multirow{2}{*}{$\begin{array}{c}\text { Service life } \\
\text { expectancy } \\
\text { (years) }^{*}\end{array}$} \\
\hline & & & 1 & II & III & & \\
\hline 1. & $\begin{array}{l}\text { Balangeran (Shorea } \\
\text { balangeran) }\end{array}$ & 134 & $1.07(1 \sim 2)$ & $1.23(1 \sim 4)$ & $2.10(1 \sim 5)$ & III (II IV) & $3 \sim 5$ \\
\hline 2. & Balau (Hopea sp.) & 2 & 1.00 & 2.00 (1 3) & $3.00(1 \sim 5)$ & III (II IV) & $4 \sim 6$ \\
\hline 3. & $\begin{array}{l}\text { bintangur (Calophyllum } \\
\text { sp.) }\end{array}$ & 62 & $1.34(1 \sim 3)$ & $1.65(1 \sim 4)$ & $1.94(1 \sim 5)$ & III & $4 \sim 5$ \\
\hline 4. & $\begin{array}{l}\text { Kempas (Koompassia } \\
\text { malaccensis) }\end{array}$ & 30 & $1.13(1 \sim 2)$ & $1.53(1 \sim 3)$ & $2.43(1 \sim 5)$ & III V & $2 \sim 5$ \\
\hline 5. & Merbau (Intsia bijuga) & 7 & 1.29 (1 2) & 1.57 (1 3) & $2.71(1 \sim 5)$ & $\mid \sim \|$ & $6 \sim 8$ \\
\hline 6. & Pasang (Querqus sp.) & 2 & 1.00 & $1.50(1 \sim 2)$ & $2.50(1 \sim 4)$ & III & $4 \sim 5$ \\
\hline 7. & $\begin{array}{l}\text { Rasamala (Altingia } \\
\text { excelsa) }\end{array}$ & 3 & $1.67(1 \sim 2)$ & $2.00(1 \sim 3)$ & $2.33(1 \sim 4)$ & III (II IV) & $3 \sim 6$ \\
\hline
\end{tabular}

Source: Oey (1990)

The wood sleepers installed at the tenth railways were replaced due to damages (e.g. break, split and cracks) caused by among others physical factors (e.g. temperature, humidity and weather), mechanical wear (friction, compression and impacts), and wood-destroying organisms (particularly fungi), as presented in Table 3 . Results of observation on service life of those wood sleepers revealed that they were in fact attacked by several species of the decaying fungi and soft-rot fungi. The attack as such still happened, although the wood stuffs at those sleepers belonged to durable classes and high-strength classes $(I \sim I)$. Further, it is necessary to note that the availability of those durable and high strength woods was getting scarce, such as teak (Tectona grandis), merbau (Intsia bijuga), ulin (Eusideroxylon zwageri), keruing (Dipterocarpus sp.), bangkirai (Shorea laevifolia Endert) and balau (Hopea sp.).

Therefore, it could be inferred that the replacement of wood sleepers at the tenth railways was mostly due to the attack by decaying fungi (brown-rot and white-rot). The decaying fungi species as encountered attacking those installed wood sleepers comprised among others Dacryopinax sp., D. spathularia Schw.(Marst), Lentinus sp., Panus sp., Pycnoporus sp., P. sanguineus Fr.(Karst), Polyporus spp., Schizophyllum commune Fr., and Trametes sp. Suprapti (2013) stated that some wood destroying fungi can attack railways wood sleeper, although it is used high resistant and strength wood (class I II). Likewise, according to Duncan and Lombard (1965), the fungi that attacked wood sleepers were among others Lentinus lepideus, Lenzites trabea, Poria spp., Schizophyllum commune, Fomes cajanderi and Merulius tremellosus. Moreover, in accordance with De Groot (1992), the degradation of wood sleeper could be affected by fungi.

The wood sleepers attacked by soft-rot fungi as well as rotting fungi were replaced, whenever the fastening or fixing screws became loose or the wood portion was no longer fastened at the metal rail. This could occur as the wood portion surrounding the screws got decayed or those screws corroded. Djarwanto and Suprapti (2008b); Suprapti and Djarwanto (2015) in their thorough inspection asserted 
that the degree of wood decay at the wood portion directly fastened or attached to the metal screws was higher than that of the control wood (without screws). In this situation, the weight loss of the wood portion directly attached to the metal screws in average was greater than that without screws or located rather far from the affixed metal screws. This strongly indicated that the chemical process that might occur to the metal screws could severely affect the degree of wood decay. This event was supported by Noetzli et al. (2007) who alleged that the use of iron nails at the wood, when getting corroded, could affect its decay. Kip and van Veen (2015) affirmed that the presence and attack of microorganisms could bring about the corrosion of metals affixed nearby (e.g. nails, hook, and fasteners). The presence and metabolism process conducted by microorganisms could take significant role on the metal corrosion. Noetzli et al. (2007) stated that the rate of wood decomposition inflicted by the rotting fungi strongly indicated that the presence of iron could enhance the fungi activities. Biological decomposition and degradation suspected to be due to wood-metal interaction in some unit in the rainforest area (De Groot 1992).

Martawijaya (1961) pointed out that from the several causes of the damages to the entire wood sleepers, and therefore should be replaced; the damage consecutively caused by rotting fungi was at $49.6 \%$ intensity; due to cracks and break equal to $1.9 \%$; to the rupture corresponding to $1.9 \%$; to the termite attack none $(0 \%)$; and to other destroying factors but unspecified at $31.2 \%$. Meanwhile, FORPRIDECOM (1971) stated that about the damages to wood sleepers of Shorea astylosa Foxw. and Vatica mangachapoi Blanco, as much consecutively $54.30 \%$ and $63.60 \%$ was brought about by the decay; consecutively $0.60 \%$ and $0.10 \%$ caused by rail-cutting; and consecutively $0 \%$ and $0.10 \%$ attributed to the spike killing. Meanwhile, regarding the damages to wood sleepers of Vitex parviflora Juss and Teijsmanniodendron aherianum Merr, as much $0.45 \%$ and $1.91 \%$ (respectively was caused by the wood decay); $0.27 \%$ and $0.17 \%$ (rail cutting); $0 \%$ and $0.09 \%$, respectively brought about by spike killing.

The life service of wood sleepers varied in figures, depending on wood species, ages of the trees when being cut down, location where the wood sleepers were installed, the traffic frequency of the trains that passed by on the railways. Likewise, according to the FAO (1957), the durability or service life of railway wood sleepers was affected by the wood species, wood drying, wood treatment, climate, burdens, bearing load, speed of trains, usage location, whether bearing plate present or not, type of fastenings, and service maintenance. Results of thorough inspection revealed that the wood sleepers of bangkirai (Shorea laevis) wood 5 months after being installed became damaged/split, and therefore necessitated replacement. This was caused by among others: the wood containing a lot of hollows (holes) inside, such hollows intentionally plugged by wood sawdust, and the wood already being attacked by the rotting fungi (Table 3 ).

Suprapti (2010) expressed her opinion that the woods that belonged to class II, when used for wood sleepers, were estimated to afford their service life for 6-7 years. Meanwhile, wood sleepers of $S$. laevis which exhibited higher quality, at 12 years in service were still intact and well installed. On the other hand, wood sleepers of asam keranji (Dialium indicum) were already completely damaged to pieces and decayed severely just 3 years after being installed at the railways. Presumably asam keranji wood as used was cut down from young trees or originated from small-diameter logs, causing their low natural resistance. According to Oey (1990), D. indicum belonged to class I, and therefore for railway sleepers was estimated to afford service life for 8 years or longer. Meanwhile, Suprapti (2010) asserted that $D$. indicum belonged to class II. To prolong the service life of wood sleepers, then besides choosing wood with high quality, the wood should be treated as well with chemical preservatives.

The State-Owned Railway Enterprise justified that wood sleepers which were not treated could perform their service life just five years after the installment, whereas wood sleepers which were treated enabled them to perform longer service life. Results of observation revealed that there were wood sleepers already installed for more than 30 years, and those sleepers looked evidently worth being used. This proved that the installed wood sleepers were of good qualities, originated from natural forests, and from oldage trees. In addition, those railway wood sleepers before being installed were previously preserved, and the species as used for such comprised among others teak wood (Tectona grandis) dan ulin wood (Eusideroxylon zwageri). Sleepers of teak wood at the railways actively passed by the trains for 50 years still revealed their condition which was worth being and still well installed. Based on the installment data and history, those wood sleepers were previously preserved with Boliden, creosote, and oil residue. Besides, the wood stuffs of those sleepers were originated from the heart wood of the old-aged trees, thereby ensuring their good quality and high resistance against the destroying organisms. Accordingly, this brought about positive effect on the wood service life. Martawijaya (1961) reported that the preservation of wood sleepers of keruing species with $4 \%$ copper-naphtenate in resex $\left(7.3 \mathrm{~kg} / \mathrm{m}^{3}\right)$ could prolong their service life three times longer ( 9 years). Further, when preserved with Boliden BIS $\left(5.8 \mathrm{~kg} / \mathrm{m}^{3}\right)$, those wood sleepers could have their service life prolonged two times longer (7 years), compared with those unpreserved (just 3 years). Meanwhile, rengas wood for railway sleepers which were preserved with copper-naphtenate $\left(10.3 \mathrm{~kg} / \mathrm{m}^{3}\right)$ could afford their service life to last 4.5 times longer (9 years), rather than only 2 years for the unpreserved sleepers. Likewise, the service life of unpreserved Pinus silvestris for railway sleepers could last only 1 year, whereas those which were preserved could do so much longer. In the Philippines, 
Table 3. Service life of several wood species for railway sleepers

\begin{tabular}{|c|c|c|c|c|c|c|}
\hline Local name & Wood species & $\begin{array}{l}\text { Destroying } \\
\text { organism }\end{array}$ & Observed condition & Grade & $\begin{array}{l}\text { Service } \\
\text { life } \\
\text { (years) }\end{array}$ & $\begin{array}{l}\text { Durability class } \\
\text { expectancy }\end{array}$ \\
\hline $\begin{array}{l}\text { Asam } \\
\text { keranii }\end{array}$ & $\begin{array}{l}\text { Dialium indicum } \\
\text { Linn. }\end{array}$ & Fungi & Completely destroyed & 5 & 3 & $1^{*}$ \\
\hline Balau & Hopea spp. & - & Still well installed & 1 & 48 & 1 \\
\hline Balangeran & $\begin{array}{l}\text { Shorea balangeran } \\
\text { Burck. }\end{array}$ & - & Still well installed & 1 & 6 & III $(\mathrm{II} / \mathrm{IV})^{*}$ \\
\hline Bangkirai & Shorea laevis Ridl. & Fungi & $\begin{array}{l}\text { Split / Completely } \\
\text { destroyed to pieces }\end{array}$ & 4 & 5 & $1^{*}$ \\
\hline Bintangur & Calophyllum sp. & - & $\begin{array}{l}\text { Split, cracks, end- } \\
\text { checks, well installed }\end{array}$ & 2 & 1 & III (II IV) * \\
\hline Bungur & $\begin{array}{l}\text { Lagerstroemia } \\
\text { speciosa Pers. }\end{array}$ & Fungi & $\begin{array}{l}\text { Split, cracks, soft texture, } \\
\text { well installed }\end{array}$ & 1 & 9 & $\|\sim\|^{*}$ \\
\hline Jati & Tectona grandis L.f. & Fungi & Cracks, well installed & 1 & 50 & $\mathrm{I}$ \\
\hline Kapur & $\begin{array}{l}\text { Dryobalanops } \\
\text { aromatic Gaertn. }\end{array}$ & - & $\begin{array}{l}\text { Cracks, soft texture, well } \\
\text { installed }\end{array}$ & 1 & 9 & $\|\sim\|^{*}$ \\
\hline Kempas & $\begin{array}{l}\text { Koompassia } \\
\text { malaccensis Maing. }\end{array}$ & Fungi & $\begin{array}{l}\text { Completely destroyed to } \\
\text { pieces }\end{array}$ & 5 & 3 & $\|I\| \sim V^{*}$ \\
\hline Keruing & Dipterocarpus sp1. & Fungi & Well installed & 1 & 3 & \|\|$^{*}$ \\
\hline Keruing & Dipterocarpus sp 2. & Fungi & $\begin{array}{l}\text { Decayed, slightly well } \\
\text { installed }\end{array}$ & 1 & 3 & $\| \mathrm{II}^{*}$ \\
\hline Nyatoh & Palaquium sp. & - & Break & 1 & 2 & $\|^{*}$ \\
\hline $\begin{array}{l}\text { Meranti } \\
\text { merah }\end{array}$ & Shorea sp 1. & Fungi & $\begin{array}{l}\text { Cracks, soft texture, well } \\
\text { installed }\end{array}$ & 1 & 3 & $|I| I \sim V^{*}$ \\
\hline $\begin{array}{l}\text { Meranti } \\
\text { merah }\end{array}$ & Shorea sp 2. & Fungi & $\begin{array}{l}\text { Decayed slightly, cracks, } \\
\text { soft texture, well installed }\end{array}$ & 1 & 3 & $|I| \sim \sim V^{*}$ \\
\hline Merbau & Intsia bijuga O. Ktze. & Fungi & $\begin{array}{l}\text { Hairy cracks, well } \\
\text { installed }\end{array}$ & 1 & 49 & $\mathrm{I}$ \\
\hline Pasang batu & Quercus lineate BI. & Fungi & Cracks, well installed & 1 & 8 & $\|^{*}$ \\
\hline Pasang & Quercus sp. & - & End check & 1 & 3 & $\mid \sim \|^{*}$ \\
\hline Puspa & $\begin{array}{l}\text { Schima wallichii } \\
\text { Korth. }\end{array}$ & - & $\begin{array}{l}\text { Cracks with curved } \\
\text { shape }\end{array}$ & 1 & 6 & \|\|$^{*}$ \\
\hline Rasamala & $\begin{array}{l}\text { Altingia excelsa } \\
\text { Noronha }\end{array}$ & - & $\begin{array}{l}\text { Cracks, smooth/soft } \\
\text { texture, well installed }\end{array}$ & 1 & 6 & $\|\sim\|^{*}$ \\
\hline Rengas & Gluta renghas L. & Fungi & $\begin{array}{l}\text { Decayed, cracks, soft } \\
\text { texture, still well installed }\end{array}$ & 1 & 2 & $\|^{*}$ \\
\hline Tusam & $\begin{array}{l}\text { Pinus merkusii Jung. } \\
\text { et De Vr. }\end{array}$ & - & $\begin{array}{l}\text { Cracks, soft texture, well } \\
\text { installed }\end{array}$ & 1 & 5 & $\mathrm{IV}^{*}$ \\
\hline $\begin{array}{l}\text { Tusam } \\
\text { Eropa }\end{array}$ & Pinus silvestris & - & $\begin{array}{l}\text { Cracks, soft texture, well } \\
\text { installed }\end{array}$ & 1 & 15 & 1 \\
\hline Ulin & $\begin{array}{l}\text { Eusideroxylon } \\
\text { zwageri T. et B. }\end{array}$ & - & $\begin{array}{l}\text { Cracks, soft texture, well } \\
\text { installed }\end{array}$ & 1 & 50 & I \\
\hline
\end{tabular}

Source: Oey (1990)

the use of wood for railway sleepers which were preserved could save as much $50 \%$ of the expended cost as those unpreserved (FORPRIDECOM 1971).

Martawijaya (1989) asserted that the resistance of rasamala wood (Altingia excelsa Noronha) cut down from the trees that grew in natural forests belonged to durability class I, while that from the trees at 48 years old growing in plantation forests belonged to class III IV. The resistance of rasamala wood from plantation forests against the rotting fungi was commensurate with the research results by Djarwanto and Suprapti (2004); Suprapti (2010), whereby through laboratory scrutiny the corresponding wood belonged to class III (II III) and III (II IV) in its resistance against the rotting fungi of Dacryopinax spathularia, Pycnoporus sanguineus, and Schizophyllum commune. On the other aspect, Suprapti and Djarwanto (2002); Suprapti (2010) asserted that the resistance of tusam wood (Pinus 
merkusii) against the rotting fungi based on the laboratory work belonged to class III (II IV) dan class II (II III).

Meanwhile, according to Martawijaya (1965a), tusam wood in fact belonged to class IV. Martawijaya (1965b) further stated that teak wood from 75 year old trees was categorized as group of being resistant to non-resistant (durability class II IV). In order to categorize wood as very resistant (durability class I), the tree should be at least 93 years old. In his research, it is turned out that as much as $85 \%$ of the wood samples had to be liquidated, due to the attack partially by fungi, and the rest by termite or fungi attacks. Martawijaya (1961) alleged that railway wood sleeper of teak wood was estimated able to last for 15 20 years. Further, when those sleepers were installed above consecutively sand ballast and stone ballast, they could last for 17 and 22 years, respectively. Records made by the Philippines National Railways showed that the treated wood of Vitex parviflora for railway crossties could last for about 25 years, while the untreated Shorea astylosa, Teijsmanniodendron aherianum, and Intsia bijuga Colebr. could do so for only 10 15 years (FORPRIDECOM, 1971).

Duncan (1960) expressed his opinion that the soft-rot fungi could attack wood material that were always wet/damp and frequently in contact with water, for example wood sleepers. Martawijaya (1983) reported that the rotting fungi hold the main role on the damage intensity as much $59.6 \%$ of 37 wood species that belonged to the Dipterocarpaceae family which were buried in the wet soil. The presence of such attack by the rotting fungi and soft-rot fungi could lower the wood strength, such that they became completely damaged to small pieces. Bruce and King (1983; 1986) stated that fungi of Lentinus lepideus species were able to attack the wood sleepers for railways, despite being already treated with creosote preservative.

\section{Conclusions}

The wood sleepers after serving for some duration necessitated replacement due to damages (break/split/ cracks and decay) which could be attributed to physical factors (e.g. temperature, humidity, sunlight and weather); mechanical wear (friction, compression and impacts), and wood-destroying organisms. Service life of wood sleeper that could last long was obtained on teak wood (Tectona grandis), balau (Hopea sp.), merbau (Intsia bijuga), and ulin (Eusideroxylon zwageri). The resistance of particular wood species at the installed railway sleepers against wood destroying organisms, especially fungi, could vary depending on the wood species, the location where and manner how the sleepers were installed, traffic frequency of the trains that passed by on the railways, and the region where the wood sleepers were placed. Those damages could occur at least 5 months age beginning from the installment of wood sleepers. The damages to railway wood sleepers as installed were mostly brought about by fungi, and so far no attack by insects occurred to those sleepers.
Fungi species as encountered attacking wood sleepers for railways comprised among others Dacryopinax sp., $D$. spathularia, Lentinus sp., Panus sp., Pycnoporus sp., $P$. sanguineus, Polyporus spp., Schizophyllum commune, and Trametes sp.

\section{Acknowledgements}

The authors want to express high appreciation and deep gratitude to the State-Owned Railway Company for greatly assisting the authors in acquiring the related data/information and providing aids for the observation on the field.

\section{References}

Amemiya, S.; S. Matsuoka. 1979. Durability of Tropical Woods. JARJA9 13(4): 256-262. Japan: Tropical Agriculture Research Center.

Bruce, A.; B. King. 1983. Biological Control of Wood Decay by Lentinus lepideus (Fr.) Produced by Scytalidium and Trichoderma Residues. Material und Organismen 18. Band 1983 Heft 3, Duncker \& Humblot - Berlin. p.: 171-181.

Bruce, A.; B. King. 1986. Biological Control of Decay in Creosote Treated Distribution Poles. Material und Organismen 21. Band 1986 Heft 1, Duncker \& Humblot - Berlin. p.: 1-13.

BSN. 2013. Standar Nasional Indonesia: SNI 0197:2013. Bantalan Kayu Rel Kereta Api. Jakarta: Badan Standardisasi Nasional (BSN).

De Groot, R.C. 1992. Test Assemblies for Monitoring Decay in Wood Exposed Above Ground. International Biodeterioration \& Biodegradation 29: 151-175.

Djarwanto; S. Abdurrohim. 2000. Wood Technology to Lengthen its Service Life. Buletin Kehutanan dan Perkebunan 1(2): 159-172.

Djarwanto; S. Suprapti. 2004. The Resistance of Three Wood Species for Railway Sleeper Against Wood Destroying Fungi in a Laboratory Experiment. Jurnal Penelitian Hasil Hutan 22(4): 215-221.

Djarwanto; S. Suprapti. 2008a. Teknologi Pengawetan Kayu untuk Bantalan Rel Kereta Api. Research Report. Center for Forest Products Technology Research and Development. Bogor-Indonesia (unpublished report).

Djarwanto; S. Suprapti. 2008b. The Effect of Metal Corrosion on the Decay of Four Wood Species Originated from Sukabumi. Jurnal IImu dan Teknologi Hasil Hutan 1(2): 55-59.

Djarwanto; S. Suprapti; U. Sudardji. 2007. Kerusakan Kayu Bantalan Rel Kereta Api. Prosiding Seminar Nasional IX MAPEKI tanggal 11-13 Agustus 2006 di Banjarbaru, p. 573-579. Faculty of Forestry, Lambung Mangkurat University, Banjar Baru, South Kalimantan. 
Djuber, SAS. 1977. Pemanfaatan Potensi Kayu Bantalan. Kehutanan Indonesia III: 11-15.

Duncan, C.G. 1960. Softrot in Wood and Toxicity Studies on Causal Fungi. American Wood-preservers Organisms. p. 1-8.

Duncan, C.G.; F.F. Lombard. 1965. Fungi Associated with Principal Decays in Wood Products in the United States. U.S. Forest Service Research Paper WO-4. Department of Agriculture Washington, DC.

FAO. 1957. Report of the ECAFE/FAO Working Party on Railway Track (Wooden) Sleepers. United Nations Economic and Social Council. E/CN.11/TRANS/ Sub.1/47. 28p.

FORPRIDECOM. 1971. Wooden Railway Ties: Their Advantages over Steel and Concrete. Technical Note 105. Philippines: Forest Products Research and Industries Development Commission.

FORPRIDECOM. 1974. Railway Spike-holding Quality of Some Philippine Woods. Technical Note 138. Philippines: Forest Products Research and Industries Development Commission.

Martawijaya, A. 1961. Some Service Test Results with Treated Sleepers. Communication Central Research Institute for Forestry Bogor-Indonesia No. 74.

Martawijaya, A. 1965a. The Influence of Tree Age on the Durability of Teak (Tectona grandis L.f.). Report No. 98. Forest Products Research Institute. Bogor.

Martawijaya, A. 1965b. The Natural Durability of Several Indonesian Coniferous Wood Species. Report No. 99. Forest Products Research Institute. Bogor.

Martawijaya, A. 1983. Keawetan Beberapa Jenis Kayu Dipterocarpaceae. Procceding Pertemuan IImiah Pengawetan Kayu. p. 157-169. Jakarta, 12-13 Oktober 1983. Forest Products Research and Development Center. Bogor.

Martawijaya, A. 1989. Keawetan Kayu yang Berasal dari Hutan Alam dan Hutan Tanaman. Proceedings Diskusi Sifat dan Kegunaan Jenis Kayu HTI, 23 Maret 1989 di Jakarta. p. 280-288. Forestry Research and Development Agency. Jakarta.

Kip N, van Veen JA. 2015. The dual role of microbes in corrosion. The ISME Journal 9: 542-551.

Noetzli, K. P.; A. B. B. Frey; F. Graf; T. S. O. Holdenrieder. 2007. Release of Iron from Bonding Nails in Torrent Control Check Dams and Its Effect on Wood Decomposition by Fomitopsis pinicola. Wood Research 52(4): 47-60.

Oey, D. S. 1990. Specific Gravity of Indonesian Woods and its Significance for Practical Use. Communication Nr.
3. Forest Products Research and Development Center. Bogor.

Perusahaan Jawatan Kereta Api. 1986. Perencanaan Konstruksi Jalan Rel (Peraturan Dinas No.10), S.K. Kepala Perusahaan Jawatan Kereta Api Tanggal 2 April 1986 No. KA/JB/18798/SK/86.

Suprapti, S. 2010. Decay Resistance of 84 Indonesian Wood Species Against Fungi. Journal of Tropical Forest Science 22(1): 81-87.

Suprapti, S. 2013. Pengelolaan Jamur Perusak Kayu untuk Mendukung Pelestarian dan Pemanfaatan Sumber Daya Hutan. Himpunan Bunga Rampai: Orasi IImiah Ahli Peneliti Utama (APU) Pusat Penelitian dan Pengembangan Keteknikan Kehutanan dan Pengolahan Hasil Hutan. ISBN 978-979-3132-44-0.

Suprapti, S.; Djarwanto. 2001. Utilization of Wood Log as a Medium of Pleurotus sajor-caju Mushroom. In Prawirohatmodjo, S.; S.N. Marsoem; A.H. Soetjipto (Eds.). Environment Conservation through Efficiency Utilization of Forest Biomass. pp: 333-340. Jogjakarta: DEBUT Press.

Suprapti, S.; Djarwanto. 2002. The Resistance of Twelve Wood Species against Six Wood Decaying Fungi. Proceedings The Fourth International Wood Science Symposium, September 2-5, Serpong. p. 164-189. Research Center for Physics, LIPI. Indonesia.

Suprapti, S.; Djarwanto. 2015. Decay Tests on Five Wood Species Fastened With Metal Screw. Jurnal Penelitian Hasil Hutan 33(4): 365-376.

Djarwanto

Laboratory of Wood Preservation,

Forest Products Research and Development Center, Jl. Gunung Batu 5. Bogor. Indonesia.

Tel. : : +62-251-8633378; Fax.: +62-251-8633413;

E-mail : djarwanto2006@yahoo.com

Sihati Suprapti

Laboratory of Mycology,

Forest Products Research and Development Center, Jl. Gunung Batu 5. Bogor. Indonesia

Sri Rulliaty

Laboratory of Wood Anatomy,

Forest Products Research and Development Center, Jl. Gunung Batu 5. Bogor. Indonesia 